This is an electronic reprint of the original article. This reprint may differ from the original in pagination and typographic detail.

Author(s): Viinikainen, Jutta; Kokko, Katja

Title: $\quad$ Personality traits and unemployment: Evidence from longitudinal data

Year: $\quad 2012$

Version:

Please cite the original version:

Viinikainen, J., \& Kokko, K. (2012). Personality traits and unemployment: Evidence from longitudinal data. Journal of Economic Psychology, 33(6), 1204-1222.

https://doi.org/10.1016/j.joep.2012.09.001

All material supplied via JYX is protected by copyright and other intellectual property rights, and duplication or sale of all or part of any of the repository collections is not permitted, except that material may be duplicated by you for your research use or educational purposes in electronic or print form. You must obtain permission for any other use. Electronic or print copies may not be offered, whether for sale or otherwise to anyone who is not an authorised user. 


\title{
PERSONALITY TRAITS AND UNEMPLOYMENT: EVIDENCE FROM LONGITUDINAL DATA
}

\author{
Jutta Viinikainen ${ }^{1}{ }^{2}$ \\ Jyväskylä University School of Business and Economics, P.O. Box 35, FI-40014 University of Jyväskylä, Finland. email: jutta.viinikainen@jyu.fi
}

Katja Kokko ${ }^{2}$

Department of Psychology, P.O. Box 35, FI-40014 University of Jyväskylä, Finland. email: Katja.r.kokko@jyu.fi.

\begin{abstract}
This study contributes to the literature on how personality is related to labour market success by providing evidence on the relationship between personality traits and unemployment. After accounting for reverse causality and measurement error, our results suggest that higher openness was associated with increased cumulative unemployment at the prime working age. It seems that this connection occurs because individuals with higher openness enter into unemployment spells more frequently - not because their unemployment spells would be particularly long.
\end{abstract}

Keywords: Personality; unemployment; stability of the Big Five personality traits; reverse causality; errors-in-variables bias.

JEL classification: J64

PsycINFO classification: 3100, 3600

\footnotetext{
${ }_{1}^{1}$ Author for correspondence. Tel. +358-40-576 7804, Fax: +358-14- 617194.

2 Katja Kokko was funded by grant Nos. 118316 and 135347 from the Academy of Finland. We are grateful to professor Lea Pulkkinen's contribution to conducting the Jyväskylä Longitudinal Study of Personality and Social Development (JYLS) over the years and her grant 127125, awarded by the Academy of Finland for the most recent JYLS data collection (2009). The use of the NEO Personality Inventory in Finnish in the JYLS is based on the permission granted to Professor Pulkkinen.
} 


\section{Introduction}

The role of personality in the labour market has received increasing interest in economics during the past decade. Empirical studies have shown that personality characteristics are related to different labour market outcomes, such as schooling decisions, occupational choices, labour force participation, and employment (for a review, e.g., Almlund et al., 2011). However, economic evidence on the relationship between personality and unemployment is still few. This paper adds to this literature by using unique data drawn from the Jyväskylä Longitudinal Study of Personality and Social Development (JYLS) (Pulkkinen, 2009), which provides information on sample individuals' personalities and work careers between the ages of 15 and 50. In line with many previous economic and psychological studies, we use for adult participants the well-established Big Five personality taxonomy (Costa \& McCrae, 1985) to describe adult personality traits (for economic applications, e.g., Braakmann, 2009; Heineck, 2011; Mueller \& Plug, 2006; Nyhus \& Pons, 2005; Uysal \& Pohlmeier, 2011; Wichert \& Pohlmeier, 2010). What is exceptional in this study is that we use information about personality characteristics at several different time points (ages 8, 33, 42 and 50) and unemployment information between the ages of 15 and 50 . This allows us to examine the potential reverse causality and errors-in-variables problems which might be related to personality measures. The links between personality traits and unemployment were analysed from three different perspectives: first, how personality traits are related to the cumulative duration of unemployment between the ages of 33 and 50; second, how personality traits are linked to the number of unemployment spells between the ages of 33 and 50; and third, how personality traits are related to the durations of single unemployment spells.

The remainder of this paper is organised as follows. Section 2 reviews some of the previous studies conducted on this topic. Section 3 describes the data we used in detail, providing descriptive statistics about the relationship between unemployment and personality traits. In section 4 we report the results concerning the relationship between personality traits and unemployment and examine whether reverse causality and errors-in-variables are likely to cause problems in estimations. Section 5 concludes the paper.

\section{How are personality characteristics related to unemployment}

Recent empirical studies in economics have found evidence that personality is likely to be linked to unemployment. Uysal and Pohlmeier (2011) concluded that, of the Big Five personality traits, conscientiousness had a positive connection with the probability of finding a job, while neuroticism had a contrasting negative connection. For women and workers with a personal migration background, openness also eased their job searches. Feinstein (2000) found that moving from the $20^{\text {th }}$ to $80^{\text {th }}$ percentile of the boys' anti-social 
disorder range at age ten increased the probability of experiencing an unemployment episode of more than four months by age of twenty-six; in contrast, extrovert boys were much less likely to experience unemployment. Among unemployed males, a higher level of self-esteem was associated with a lower probability of long-term unemployment (i.e., unemployment lasting more than 12 months). Female unemployment, on the other hand, seems to depend more on poor peer relations and inattentiveness measured at age ten, and girls with a high level of self-esteem were more likely to have long periods of unemployment. (Feinstein, 2000.) In contrast, Gallo, et al. (2003) found that an internal locus of control was associated with a higher probability of reemployment following a job loss. Furthermore, psychological literature provides evidence on the connection between personality characteristics and unemployment (e.g., Caspet al., 1998; Doodley \& Prause, 1995, 1997; Ferguson et al., 1997; Hintsanen et al., 2009; Kokko, Bergman \& Pulkkinen, 2003; Kokko \& Pulkkinen, 2000; Winefield et al., 1991).

Mueller and Plug (2006) distinguished three alternative ways in which personality might matter in the labour market, and their categorisation schema can also be applied to those who are unemployed. The categorisation of Mueller and Plug is as follows. 1) Differences in skills: personality can be seen as a set of qualities, all of which contribute to productivity. As far as these qualities can be signalled to potential employers, certain personality aspects might increase or decrease the probability of receiving a job offer. Similarly, personality-related skills might affect the probability of losing a job. 2) Differences in preferences: personality might be linked to preferences, such as attitudes towards leisure and job search efforts. It is also possible that personality affects occupational choices. Because the probability of unemployment differ among occupations it could be that variations in unemployment across individuals with differing personalities might well be a natural outcome of well-functioning labour market that sorts workers into jobs which satisfy their individual preferences (Filer, 1986). 3) Labour market discrimination: certain characteristics might affect, for instance, the frequency of job offers or the probability of dismissal, although such characteristics do not affect the individual's actual competence or productivity. Another way to approach the connections between personality and unemployment is so called mechanism of cumulative continuity (Caspi, Elder, \& Bem, 1987). This means that certain behaviors have accumulated consequences across time, such as that child aggression precedes adolescent school maladjustment and young adult problem drinking which are further linked to later long-term unemployment (Kokko \& Pulkkinen, 2000).

Previous studies suggest that at least the first two explanations of Mueller and Plug are likely to account for individuals' differences in experienced unemployment. Tokar et al. (1998) and Burch and Anderson (2009) review articles that have found connections between personality, job performance and productivity. Supporting the second explanation, studies which concentrate on personality and job searching (e.g. Caliendo et al., 2010; DellaVigna \& Paserman, 2005; McGee, 2010) have commonly found that personality traits are 
related to both job seeking behaviour and reservation wages (and thus the duration of unemployment). In addition, there is evidence that personality characteristics are related to labour market participation (e.g., Mohanty, 2010; Wichert \& Pohlmeier, 2009). Furthermore, empirical evidence also suggests that personality traits are likely to affect occupational choices (e.g., Filer, 1986; Barrick \& Mount, 1991; Heckman, Stixrud \& Urzua, 2006; Cobb-Clark \& Tan, 2009; Antecol and Cobb-Clark, 2010). For example, leadership studies suggest that extraversion, in particular, is positively related to leadership (Burch \& Anderson, 2009: 754-755).

The usual premise in economic literature is that personality characteristics affect labour market outcomes, such as earnings and unemployment. However, it is also possible that personality characteristics are shaped by success or failure in the labour market; thus, the causal relationship between personality characteristics and labour market outcomes is ambiguous. The potential for reverse causality is repeatedly highlighted in the literature (e.g., Borghans et al., 2008); unfortunately, data limitations tend to make it impossible to empirically examine or to correct for the potential reverse causality. The problem of potential reverse causality or simultaneity bias is often overcome by assuming that personality characteristics, particularly the Big Five personality traits, are stable during adulthood. This assumption is convenient because it implies that personality traits are exogenous and not driven by a given outcome variable, so personality traits can be measured even after the outcome variable (Cobb-Clark \& Schurer, 2011). Another typical way of overcoming the problem of reverse causality in estimations is to use personality measures, which were obtained before the labour market outcome of interest (i.e., lagged personality measures). Unfortunately, both of these solutions are problematic. First, as will be discussed next, it is problematic to assume that personality traits are completely stable. Second, the use of lagged personality traits does not necessarily eliminate the possibility of reverse causality because it is possible that previous labour market experiences have already shaped personality characteristics. Furthermore, if personality traits and the outcome variable were measured at different times, changes in personality would cause an errors-in-variables bias in the estimates.

The extensive psychological literature concerning the stability of the Big Five personality traits (for a recent review, e.g., Specht et al., 2011) focuses on two different stability measures: 1) mean level stability, the stability or change over time in absolute levels of a trait; and 2) rank order stability, the stability or change in the ordinal ranking of individuals in a trait in question. Despite the existence of multiple studies on this topic, there is still no consensus on the stability of the Big Five personality traits. Studies concerning the mean level stability show either that the traits stabilise after age 30 (e.g., Costa \& McCrae, 1994; McCrae \& Costa, 2006) or, based on a significant amount of evidence, that the traits do change through midlife and that these changes are more than trivial (e.g., Srivastava et al. 2003; Roberts et al., 2006; Specht et al., 2011). In regards to the rank order stability of the personality traits, according to a meta- 
analysis by Roberts and DelVecchio (2000), the stability consistently increases from childhood to age 30 and then stabilises between the ages of 50 to 70 years. It is also possible that rank-order stability follows a quadratic function (inverted U-form) with a peak at age 50 and a decrease afterwards, as suggested by Ardelt (2000). Specht et al. (2011) also found that, whereas conscientiousness showed continuously increasing rank-order stability across adulthood, the other Big Five personality traits followed an inverted U-shaped function reaching a peak between the ages of 40 and 60 and then decreasing afterwards. Furthermore, in the JYLS, considerable rank-order stability (ranging from 0.65 to 0.97 ) in the Big Five traits has been observed from the age of 33 to 42 years (Rantanen et al., 2007).

Although we would agree that personality characteristics change, this does not necessarily mean that reverse causality exists. We must determine why these changes occur and what are the major causes underlying these processes. The changes in personality traits have been attributed to two sources: genetic and environmental factors (e.g Specht et al., 2011). Previous literature, going all the way back to Eisenberg and Lazarsfeld (1938), suggests that unemployment affects personal characteristics and mental health (e.g., Murphy \& Athanasou, 1999). In the context of the Big Five, McCrae and Costa (2008) state that life events have very little effect on personality traits, while Bleidorn et al. (2009) showed in a longitudinal twin study that changes in these traits can be substantially attributed to both genetic factors and environmental factors and Scollon and Diener (2006) indicated that an increased work satisfaction was connected to an increase in extraversion. If the changes in personality traits are solely caused by genes, reverse causality should not be a problem. On the other hand, if life events, particularly unemployment in our case, causes changes in personality, the question of causality is relevant. According to Specht et al. (2011), unemployment was associated with a decrease in the mean level of openness whereas emotional stability and openness were associated with a decrease in the rank order stability. However, in both cases the results were significant only at the $10 \%$ level. Related to this literature, Sutin and Costa (2010) found that personality traits were associated with changes in occupational experiences but none of the job characteristics predicted changes in personality at the factor level. Furthermore, Sutin, Costa, Miech and Eaton (2009) showed that, among young individuals, a higher baseline of income predicted decreases in neuroticism.

\section{Longitudinal data and descriptive statistics}

The longitudinal data used in the empirical part of this study were drawn from the Jyväskylä Longitudinal Study of Personality and Social Development (JYLS), conducted by Pulkkinen (see Pitkänen, 1969; Pulkkinen, 2009). This study began in 1968 when 12 entire school classes from the Jyväskylä area were randomly selected; the initial attrition rate was zero. The 369 children of the 
initial sample were mainly born in 1959, and in 1968, they were 8 years old and in the second grade. The sample represented approximately 40 percent of the second graders in the area. Since 1968, data have been gathered at ages 14 (1974), 20 (1980), 27 (1986), 33 (1992), 36 (1995), 42 (2001), and 50 (2009).

At age 8 , the main methods of data collection were teacher ratings and peer nominations, whereas in adulthood, questionnaires and personal interviews were used. The dataset provides information (among other things) on educational attainment, unemployment, and personality. The data on unemployment were obtained from Life History Calendars, adapted from Caspi et al. (1996), which were filled out by the participants together with their interviewers at ages 42 and 50. ${ }^{3}$ In addition, the participants filled out Life Situation Questionnaires at ages 27, 36, 42 and 50, at which times information about unemployment was inquired. These different data sources were used to ensure the reliability of the data. The child personality characteristics were measured at age 8 , and they were based on teachers' ratings. The seven child personality characteristics measured are constructiveness, anxiety, emotional stability, aggression, compliance, emotional lability and social activity, and they were measured using between 1 and 8 items (Pulkkinen, Kokko, \& Rantanen, 2012). In the present study, the adult personality was measured at ages 33, 42 and 50 by using a shortened version (with 60 items) of the Big Five Personality Inventory (Pulver et al., 1995), which is an authorised Finnish adaption of Costa and McCrae's (1985) NEO Personal Inventory (NEO-PI) and in which approximately one-tenth of the items are substitutes for the original American items.

The Big Five consists of five personality traits: openness to new experiences, conscientiousness, extraversion, agreeableness, and neuroticism. In the shortened version, each of these traits contains 12 items. Eight items are substitutes for the original American items to reflect differences in culture and society. Individuals were asked to rate the extent to which they agreed with each statement on a five-point scale $(1=$ strongly disagree, $5=$ strongly agree $)$. The mean scores of all 12 items for each trait were calculated and used as indicators of the strength of the traits in an individual. The reliabilities of the personality traits at age 33, assessed by Cronbach's alpha, were as follows: Neuroticism, 0.86 for men and 0.85 for women; Extraversion, 0.84 for men and 0.70 for women; Openness, 0.78 for both genders; Agreeableness, 0.79 for men and 0.77 for women; and Conscientiousness, 0.75 for men and 0.78 for women. ${ }^{4}$

\footnotetext{
3 The participants filled out with an interviewer a Life History calendar at ages 42 and 50 where different life events (rows in the calendar) such as family events, education and employ-ment/unemployment history were recorded annually. For each event, the interviewer recorded the age at which it started, its continuation (if relevant) and the age when it finished.

${ }^{4}$ At age 42, the Cronbach's alphas were as follows: Neuroticism, 0.83 for women and 0.90 for men; Extraversion, 0.76 for women and 0.83 for men; Agreeableness, 0.79 for both genders; Conscientiousness, 0.79 for women and 0.76 for men; and Openness, 0.81 for women and 0.75 for men. At age 50, the Cronbach's alphas were as follows: Neuroticism, 0.77 for women and 0.78 for men; Extraversion, 0.78 for women and 0.80 for men; Agreeableness, 0.73 for women and 0.75 for men; Conscientiousness, 0.78 for women and 0.80 for men; and Openness, 0.77 for women and 0.72 for men.
} 
Adjectives such as artistic, curious, imaginative, and wide interests describe an individual who exhibits a high level of openness to experience; organised, planful, reliable, and responsible describe an individual high in conscientiousness; active, assertive, enthusiastic, and outgoing describe an individual high in extraversion; generous, kind, sympathetic, and trusting describe an individual high in agreeableness; and anxious, self-pitying, tense, and worrying describe an individual high in neuroticism (Caspi, 1998: 317). Each of these factors consists of a number of more specific facets.

The participation rate of the JYLS has remained high over the years (Pulkkinen \& Kokko, 2012). At age 50, the participation rate was $84 \%(n=271$; calculated from the initial sample of 369 children excluding those participants who had died, $n=12$, and declined entirely from the study, $n=34$ ). The retention rate calculated from the initial sample was $73 \%$. Regarding attrition over the years, a comparison of the participants and non-participants at age 42 (in 2001) and 50 (in 2009) revealed that the participants continued to represent the initial random sample in terms of socioemotional behaviour in childhood and school achievement in adolescence (Pulkkinen, 2006; Pulkkinen \& Kokko, 2010). Furthermore, they were representative of the Finnish age-cohort born in 1959 with respect to (for example) marital status, number of children, employment, and unemployment according to the statistics provided by Statistics Finland. In terms of educational attainment, the male participants did not differ from their age cohort group; female participants in turn had a vocational college education (e.g., nurse, ISCED level 5B) in a slightly higher percentage than did females in their age cohort group within the general population. Due to missing information in several core variables, the subsample we used in this study $(n=151)$ was smaller than the total sample of $2001(n=285)$ and of $2009(n=271)$. For these 151 individuals, there was information regarding the Big Five personality traits at ages 33,42 , and 50 as well as information regarding all of the background variables that were used in this study. In particular, we encountered information gaps concerning the Big Five personality traits at age 33, which were obtained by mailed questionnaires without a contact through a personal interview (at ages 42 and 50 also interviews were conducted); therefore, the sample size used in this paper was smaller than the participation rates in general. We tested the randomness of this attrition by using a twogroup test of proportions between the total sample of 2001 and our subsample. According to our results, the attrition between the sample of 2001 and our estimation sample was mostly random. The only exceptions were gender and the stability of an individual's work career: in our estimation sample, there were more females (57\%) compared to the sample from $2001(47 \%)$, and there were also more individuals with a stable work career in our sample $(82 \%)$ compared to the total sample from 2001 (74 \%). ${ }^{5}$

5 The two-group test of proportions in Stata 10.0 was used to test whether the proportions of the following groups were equal in the 2001 sample and in the subsamples we used in Tables (6) and (7): gender, family's socioeconomic status in 1968 (3 dummy variables), level of education (4 dummy variables), and stability of work career ( 3 dummy variables). Rejection of the null hypothesis would indicate that the proportion of e.g. females was 
Figure 1 and Table 1 illustrate the differences in personality traits at age 33 between individuals who did and did not experience unemployment between the ages of 33 and 50. Figure 1 graphs the kernel density estimates of personality trait measures by employment status, whereas Table 1 tabulates the means and standard deviations as well as t-test p-values for the equality of means and the Kolmogorov-Smirnov p-values for the equality of distributions. According to Figure 1 and Table 1, the distributions of personality traits were mostly similar among those who did and did not experience unemployment between the ages of 33 and 50. The only exceptions were openness and conscientiousness; the mean level and standard deviation of openness were higher among those who had experienced unemployment, whereas the mean score of conscientiousness was higher while the standard deviation of conscientiousness was lower among those who had not experienced unemployment.
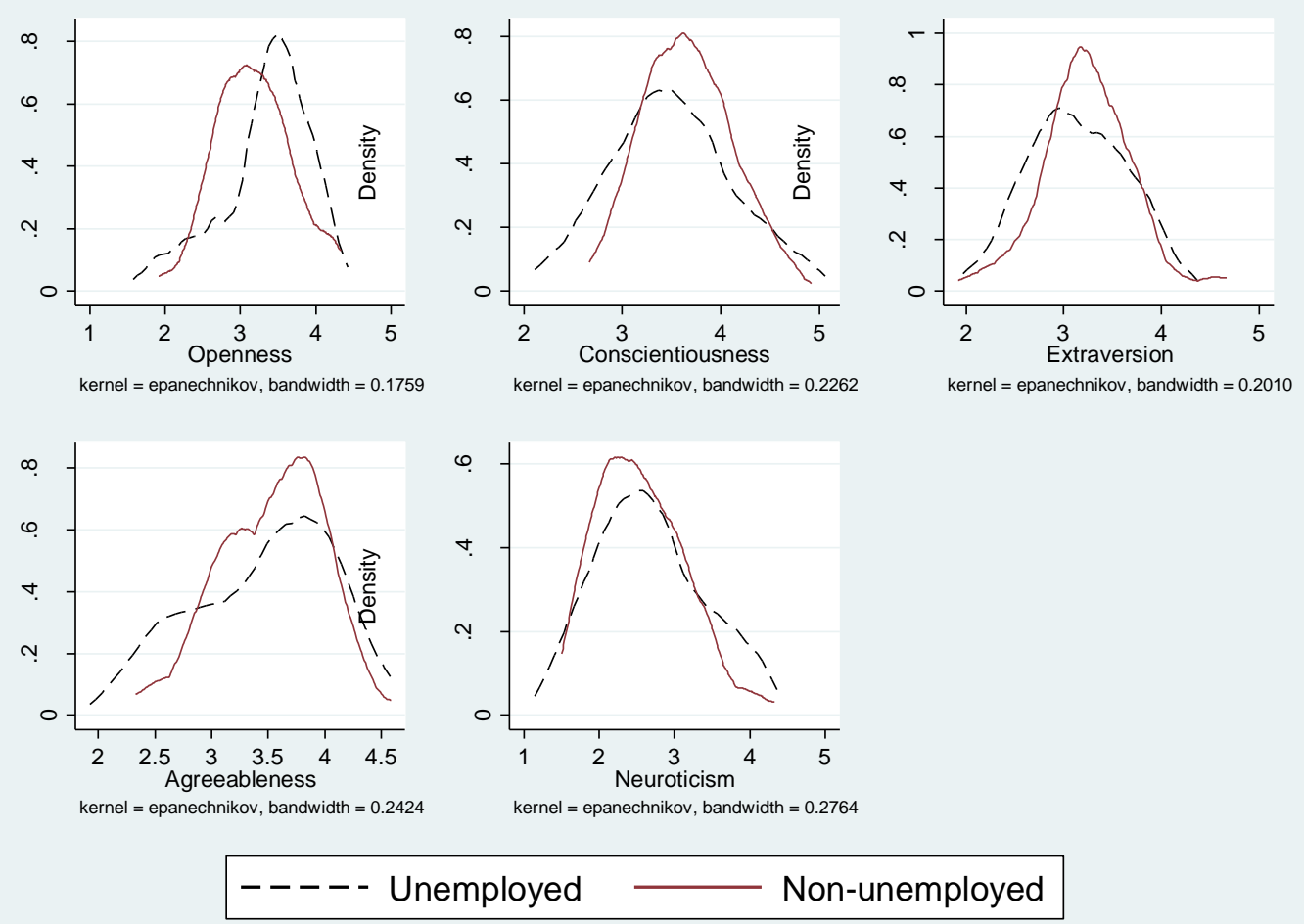

FIGURE 1 Distribution of the Big Five personality traits at age 33 in the sample by employment status at ages 33-50.

different in the total sample of 2001 and in our subsample. In other words, attrition between the 2001 sample and our subsample would not be random. Attrition was not tested in Table (8) because there the attrition is not likely to be random since only individuals, who were unemployed between ages 33 and 50 were used in estimations. 
TABLE 1 Means and distributions of the Big Five personality traits at age 33 by employment status at ages 33-50.

\begin{tabular}{|c|c|c|c|c|c|c|}
\hline & \multicolumn{2}{|c|}{ Non-unemployed } & \multicolumn{2}{|c|}{ Unemployed } & \multirow[t]{2}{*}{$\begin{array}{c}\text { t-test } \\
\text { p-value }\end{array}$} & \multirow[t]{2}{*}{$\begin{array}{c}\text { Kolmogorov- } \\
\text { Smirnov } \\
\text { p-value }\end{array}$} \\
\hline & Mean & $S D$ & Mean & $S D$ & & \\
\hline Openness & 3.179 & 0.517 & 3.337 & 0.593 & 0.092 & 0.011 \\
\hline Conscientiousness & 3.657 & 0.459 & 3.496 & 0.606 & 0.069 & 0.090 \\
\hline Extraversion & 3.243 & 0.482 & 3.138 & 0.494 & 0.208 & 0.304 \\
\hline Agreeableness & 3.533 & 0.459 & 3.452 & 0.596 & 0.357 & 0.153 \\
\hline $\begin{array}{l}\text { Neuroticism } \\
\text { Number of } \\
\text { individuals }\end{array}$ & 2.561 & 0.600 & 2.671 & 0.700 & 0.311 & 0.717 \\
\hline
\end{tabular}

Table 2 further illustrates the relationships between the Big Five personality traits and unemployment by tabulating the correlations between them. We used three different measures for unemployment: the cumulative duration of unemployment between the ages of 33 and 50 (column 1), the number of unemployment spells between the ages of 33 and 50 (column 2), and the durations of single unemployment spells between the ages of 33 and 50 (column 3). The cumulative duration of unemployment is a function of the number of unemployment spells and the durations of single unemployment spells. In columns 1 and 2, personality traits were measured at age 33, while in column 3, personality traits were measured at age 33 if an unemployment spell started between the ages of 33 and 41; if the unemployment spell started later, personality traits were measured at age $42 .{ }^{6}$ An unemployment spell was considered as ended irrespective of the reason for the unemployment exit. For example, besides re-employment, the reason for an unemployment exit may have been to pursue further education. Overall, only a few of the correlations were statistically significant. Agreeableness had negative correlations with the duration of cumulative unemployment and extraversion had a negative correlation while neuroticism a positive correlation with the durations of single unemployment spells.

\footnotetext{
6 Unemployment information was gathered at ages 42 (ages 33-42) and 50 (ages 42-50). For some individuals, however, the unemployment information was missing for one or the other time span. To increase the number of observations, we have also used the individuals with (partly) missing information in models where the durations of single unemployment spells were used as the dependent variable. In models where the dependent variable was cumulative unemployment or the number of unemployment spells only individuals with non-missing unemployment information were included in estimations. In columns (1) and (2), zero observations were also used in the analysis.
} 
TABLE 2 Correlations between personality traits and unemployment between ages 33 and 50 .

\begin{tabular}{|c|c|c|c|}
\hline & $\begin{array}{c}\text { (1) } \\
\text { Cumulative } \\
\text { duration of } \\
\text { unemployment }\end{array}$ & $\begin{array}{c}(2) \\
\text { Number of } \\
\text { unemployment } \\
\text { spells } \\
\end{array}$ & $\begin{array}{c}(3) \\
\begin{array}{c}\text { Durations of single } \\
\text { unemployment } \\
\text { spells }\end{array} \\
\end{array}$ \\
\hline Openness & 0.103 & 0.115 & 0.028 \\
\hline Conscientiousness & -0.066 & -0.033 & -0.084 \\
\hline Extraversion & -0.130 & -0.108 & $-0.168^{* *}$ \\
\hline Agreeableness & $-0.196^{* *}$ & -0.090 & -0.096 \\
\hline Neuroticism & 0.091 & 0.111 & $0.151^{* *}$ \\
\hline $\mathbf{N}$ & \multicolumn{2}{|c|}{151} & 170 \\
\hline
\end{tabular}

Significant at * $10 \%, * * 5 \%, * * * 1 \%$ level.

The number of observations in Table 2 is the same as in Tables 4-6. Note that in column (3) one individual can have multiple unemployment spells but this was not taken into account in the correlations.

The Big Five personality traits are not fully orthogonal to one another, which means that they are not independent (see e.g., Musek, 2007). Table 3 tabulates the correlations between the Big Five personality traits at age 33 based on the sample used in this study. There are significant although quite small positive correlations between openness and extraversion as well as openness and agreeableness whereas small negative correlations appear between neuroticism and conscientiousness, extraversion and agreeableness. A high correlation between regressors causes multicollinearity but even high multicollinearity does not lead to biased estimates. However, multicollinearity is likely to increase the standard errors and therefore cause mistakenly a coefficient to be insignificant.

TABLE 3 Correlations between the Big Five personality traits at age 33.

\begin{tabular}{|c|c|c|c|c|c|}
\hline & 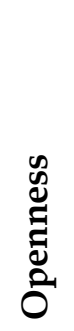 & 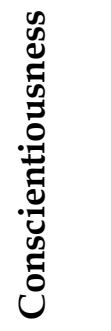 & 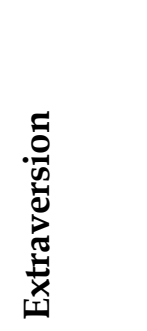 & 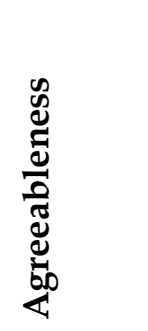 & 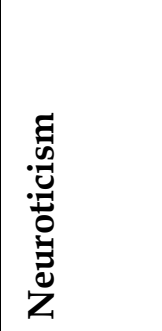 \\
\hline Openness & 1 & -0.123 & $0.277^{* * *}$ & $0.250 * * *$ & -0.054 \\
\hline Conscientiousness & & 1 & 0.090 & -0.054 & $-0.257^{* *}$ \\
\hline Extraversion & & & 1 & 0.122 & $-0.272^{* * *}$ \\
\hline Agreeableness & & & & 1 & $-0.164^{\star *}$ \\
\hline Neuroticism & & & & & 1 \\
\hline
\end{tabular}

$\mathrm{N}=151$. Significant at * $10 \%$, ** $5 \%$, *** $1 \%$ level. 


\section{Evidence on personality traits and subsequent unemployment}

\subsection{Personality traits and unemployment: evidence from three perspectives}

In this section, we will illustrate the relationship between personality traits and unemployment using three different approaches. First, the cumulative duration of unemployment is regressed by using Tobit estimation. Second, the number of unemployment spells is estimated by Poisson regression, and finally, we use a discrete time-proportional hazard model to illustrate the durations of single unemployment spells.

We begin with a model in which the cumulative duration of unemployment between the ages of 33 and 50 was regressed on personality traits, education, profession, indicators for metropolitan areas, gender, and marital status by using the Tobit model (Tobin, 1958):

$$
y_{i}^{*}=x_{i}^{\prime} \beta+\varepsilon_{i} \quad \varepsilon \sim N\left(0, \sigma^{2}\right) .
$$

In equation (1), $y_{i}^{*}$ is a latent index, which captures the tendency of an individual to experience unemployment; $x_{\mathrm{i}}$ is a vector of independent variables; and $\varepsilon_{i}$ is a normally distributed error term. Let $a$ be the lower censored limit and $b$ the upper censored limit. 7 The Tobit model can then be expressed by the following relationship:

$$
\text { (2) } y_{i}=\left\{\begin{array} { c } 
{ y _ { i } ^ { * } } \\
{ a } \\
{ b }
\end{array} \quad \text { if } \quad \left\{\begin{array}{c}
a<y_{i}^{*}<b \\
y_{i}^{*} \leq a \\
y_{i}^{*} \geq b
\end{array}\right.\right.
$$

Table 4 tabulates the standardised average marginal effects on the expected value for $y$ for uncensored observations. ${ }^{8}$ Column (1) tabulates the results from the basic model, which uses only the Big Five personality traits as explanatory variables; column (2) augments the model with education, occupation, gender and indicators for married individuals and citizens of metropolitan areas; column (3) augments the model with previous cumulative unemployment between the ages of 15 and 33; and column (4) augments the model with child personality characteristics.

The results in Table 4 indicate that openness, extraversion and agreeableness were associated with the cumulative duration of unemployment in all four model specifications. One standard deviation increase in openness

7 The lower censoring limit, $a$, was 0 months, and there were no right censored observations.

8 Total results are tabulated in Appendix A. 
Table 5 reports the results from a model in which the number of unemployment spells between the ages of 33 and 50 was used as the dependent variable. ${ }^{9}$ We used the Poisson regression model with robust standard errors, as recommended by Cameron and Trivedi (2009), to control for a violation of the distribution assumption that the variance equals the mean. ${ }^{10}$ The primary equation of the model is:

(3) $\quad \operatorname{Pr} o b\left(Y_{i}=y_{i} \mid x_{i}\right)=\frac{e^{-\lambda_{i}} \lambda_{i}^{y_{i}}}{y_{i} !}, y_{i}=0,1,2, \ldots$

where $Y_{i}$ refers to the number of unemployment spells of an individual $i$, and each $y_{i}$ is drawn from a Poisson distribution with parameter $\lambda_{i}$, which is related to regressors $x_{i}$. Table 5 presents the estimation results from the four different model specifications where the set of explanatory variables in column (1) includes only personality traits obtained at age 33; the second column augments the model with education, occupation, gender, and indicators for married individuals and citizens of metropolitan areas; the third column augments the model with previous unemployment; and column four augments the model with child personality characteristics. Similar to Table 4, openness and extraversion were significant in all four model specifications, suggesting that one standard deviation increase in openness was associated with an approximately 0.4 to 0.7 unit increase in the number of unemployment spells. A similar change in extraversion was associated with an approximately 0.3 to 0.7 unit reduction in the number of unemployment spells.

\footnotetext{
9 Total results are tabulated in Appendix B.

10 We also estimated the model by negative binomial regression, which is a model for count variables in the case where the variance of the dependent variable is significantly larger than the mean (i.e. overdispersion). The results obtained by this method were qualitatively similar to those in Table 5.
} 
TABLE 5 Personality and the number of unemployment spells (Poisson model).

\begin{tabular}{|c|c|c|c|c|}
\hline & (1) & (2) & (3) & (4) \\
\hline \multirow[t]{2}{*}{ Openness (age 33) } & $0.419^{* *}$ & $0.590 * * *$ & $0.551^{* *}$ & $0.700^{* * *}$ \\
\hline & $(0.212)$ & $(0.221)$ & $(0.231)$ & $(0.243)$ \\
\hline \multirow[t]{2}{*}{ Conscientiousness (age 33) } & 0.048 & 0.082 & 0.064 & 0.028 \\
\hline & $(0.180)$ & $(0.176)$ & $(0.178)$ & $(0.154)$ \\
\hline \multirow[t]{2}{*}{ Extraversion (age 33) } & $-0.288^{*}$ & $-0.503^{* *}$ & $-0.482^{* *}$ & $-0.704^{* * *}$ \\
\hline & $(0.163)$ & $(0.230)$ & $(0.226)$ & $(0.222)$ \\
\hline \multirow[t]{2}{*}{ Agreeableness (age 33) } & -0.229 & -0.121 & -0.226 & -0.159 \\
\hline & $(0.213)$ & $(0.202)$ & $(0.200)$ & $(0.163)$ \\
\hline \multirow[t]{2}{*}{ Neuroticism (age 33) } & 0.155 & -0.041 & -0.087 & -0.110 \\
\hline & $(0.205)$ & $(0.172)$ & $(0.173)$ & $(0.161)$ \\
\hline Controls: basic ${ }^{a}$ & & $x$ & $x$ & $x$ \\
\hline Controls: Unemployment ages $15-33$ & & & $x$ & $x$ \\
\hline Controls: Child personality characteristics ${ }^{b}$ & & & & $x$ \\
\hline Pseudo R2 & 0.0598 & 0.1936 & 0.2180 & 0.2835 \\
\hline $\mathbf{N}$ & & & & \\
\hline
\end{tabular}

The table tabulates the standardised average marginal effects. Standard errors, obtained by the delta method, are shown in parentheses. Significant at * $10 \%$, ** $5 \%$, *** $1 \%$ level. Also, individuals with zero unemployment spells were included in the estimations.

a The following control variables were also included: Level of education (4 dummies), an indicator for metropolitan areas, occupational status (3 dummies), gender, and an indicator for those who have been married between the ages of 15 and 42 .

b The child personality characteristics were as follows: emotional stability, social activity, constructiveness, anxiety, aggression, emotional lability, and compliance.

Finally, we estimated the durations of single unemployment spells that started between the ages of 33 and 50. Because some individuals had multiple spells during this period, the total number of unemployment spells exceeded the number of individuals. We estimated the unemployment durations using a discrete time-proportional hazard regression model by applying a maximumlikelihood complementary log-log model with a fully non-parametric baseline hazard. The complementary log-log discrete time hazard function $p(t)$ is defined as:

$$
\begin{aligned}
& p(t)=1-\exp [-\exp (z(t))], \quad \text { where } \\
& z(t)=c(t)+\beta^{\prime} X_{i} .
\end{aligned}
$$

In equation (4), $i$ refers to the individual, $c(t)$ is the baseline hazard function and $\beta^{\prime} X$ includes explanatory variables and an intercept term. If the unemployment spell started between the ages of 33 and 41, we used the personality trait measures that were obtained at age 33 , and if the unemployment spell started 
later, the personality trait measures were obtained at age 42 . Table 6 tabulates the exponential coefficients from this model, which can be interpreted as hazard ratios. ${ }^{11}$ As before, column (1) tabulates the results from a model where only personality traits were used as explanatory variables. Column (2) augments the model with education, occupation, gender, marital status, and area of residence; column (3) augments the model with previous unemployment; and column (4) augments the model with child personality characteristics.

The results in Table 6 suggest that neuroticism in particular was associated with a decreased probability of unemployment exit (i.e., a longer duration of a single unemployment spell). In addition, agreeableness was significant in column (4); however, the personality traits were otherwise insignificant. The results concerning neuroticism were in line with Uysal and Pohlmeier (2011), who also found that the Big Five neuroticism trait decreased the probability of finding a job. Uysal and Pohlmeier also found conscientiousness to have a positive relationship with the probability of finding a job, but our results in Table 6 did not support this finding.

11 Total results are tabulated in Appendix C. 
TABLE 6 Durations of single unemployment spells (discrete time proportional hazard regression model).

\begin{tabular}{|c|c|c|c|c|}
\hline & (1) & (2) & (3) & (4) \\
\hline \multirow[t]{2}{*}{ Openness } & 0.879 & 0.923 & 0.944 & 0.857 \\
\hline & $(0.079)$ & $(0.119)$ & $(0.128)$ & $(0.083)$ \\
\hline \multirow[t]{2}{*}{ Conscientiousness } & 1.013 & 1.020 & 0.990 & 1.015 \\
\hline & $(0.138)$ & $(0.168)$ & $(0.141)$ & $(0.144)$ \\
\hline \multirow[t]{2}{*}{ Extraversion } & 1.092 & 1.100 & 1.042 & 0.966 \\
\hline & $(0.106)$ & $(0.110)$ & $(0.108)$ & $(0.141)$ \\
\hline \multirow[t]{2}{*}{ Agreeableness } & 1.047 & 1.058 & 1.068 & $1.300^{*}$ \\
\hline & $(0.149)$ & $(0.228)$ & $(0.210)$ & $(0.190)$ \\
\hline \multirow[t]{2}{*}{ Neuroticism } & 0.794 & $0.672^{*}$ & $0.614^{* *}$ & $0.593^{* *}$ \\
\hline & $(0.154)$ & $(0.141)$ & $(0.118)$ & $(0.130)$ \\
\hline Controls: basic ${ }^{a}$ & & $x$ & $x$ & $x$ \\
\hline Controls: Unemployment ages $15-33$ & & & $x$ & $x$ \\
\hline Controls: Child personality characteristics ${ }^{b}$ & & & & $x$ \\
\hline McFadden's adj. R2 & 0.133 & 0.148 & 0.150 & 0.162 \\
\hline Number of unemployment spells & \multicolumn{4}{|c|}{158 non-censored, 12 censored } \\
\hline Number of individuals & \multicolumn{4}{|c|}{56} \\
\hline \multicolumn{5}{|c|}{$\begin{array}{l}\text { The table tabulates the standardised hazard rates followed by robust standard errors which are } \\
\text { adjusted by clustering by individuals. If the unemployment spell started between the ages of } 33 \\
\text { and } 41 \text {, we used the personality trait measures that were obtained at age } 33 \text {, and if the } \\
\text { unemployment spell started later, the personality trait measures were obtained at age } 42 \text {. } \\
\text { Significant at * } 10 \% \text {, ** } 5 \% \text {, *** } 1 \% \text { level. } \\
\text { a) The following control variables were also included: Level of education ( } 4 \text { dummies), an } \\
\text { indicator for metropolitan area, occupational status ( } 3 \text { dummies), gender, and an indicator for } \\
\text { those who have been married between the ages of } 15 \text { and } 42 \text {. } \\
\text { b) The child personality characteristics were as follows: emotional stability, social activity, } \\
\text { constructiveness, anxiety, aggression, emotional lability, and compliance. }\end{array}$} \\
\hline
\end{tabular}

\subsection{Stability of personality traits and reverse causality}

In section 2, we discussed the potential reverse causality problem. This section empirically examines to what extent reverse causality is likely to affect our results. To reduce the problem of reverse causality, we used lagged measures of personality traits in this study (i.e., personality measures that were obtained at age 33), meaning that they were measured before the unemployment spells we focused on. However, it is possible that previous unemployment has already affected the lagged Big Five personality traits at age 33, which would induce the problem of reverse causality. To test this possibility, we estimated models in which each of the Big Five personality traits at age 33 was regressed on i) a dummy variable for individuals who had experienced at least one 
unemployment spell between the ages of 15 and 33; ii) the duration of cumulative unemployment between the ages of 15 and 33; or iii) the number of unemployment spells between the ages of 15 and 33. Besides unemployment $(U)$ the model was augmented with controls for education, occupation, gender and marital status measured at age $33(X)$ as well as child personality characteristics at age $8(C)$ :

$$
P_{i, q, 33}=\alpha_{q}+\beta_{q} X_{i, 33}+\delta_{q} C_{i, 8}+\theta_{q} U_{i, 15-33}+\varepsilon_{i, q},
$$

In equation (5), $i$ refers to an individual, $q$ refers to the different personality traits, and $\varepsilon$ is a stochastic error term. The results are tabulated in Appendix D (Tables D.1-D.3). The results in Table D.1 show that when conscientiousness or extraversion was used as the dependent variable, the unemployment indicator was negative and significant in all model specifications. In one model specification the relationship between unemployment and openness was also negative and significant. In Tables D.2 and D.3, the coefficients for previous unemployment were overall small and insignificant; however, in some of the model specifications, previous unemployment had a significant negative effect on conscientiousness and agreeableness and a significant positive effect on neuroticism. If we increased the sample size $(n=167)$ by including those with no information regarding their personality traits at ages 42 or 50 into our estimations the results were slightly different. In this case cumulative unemployment and the number of unemployment spells had a significant positive effect on neuroticism and also the negative effect of unemployment on extraversion was pronounced. Thus, it seems that previous unemployment has affected some of the personality traits at the age of 33 .

To further illustrate the relationship between personality traits and unemployment, we also estimated models in which the change in the individual level of each of the Big Five personality traits between the ages of 33 and 50 was regressed on exogenous variables $(X)$ and i) a dummy variable for individuals who had experienced at least one unemployment spell between the ages of 33 and 50; ii) the duration of cumulative unemployment between the ages of 33 and 50; or iii) the number of unemployment spells between the ages of 33 and 50. The results tabulated in Appendix D (Tables D.4-D.6) show, that the unemployment measure was marginally significant in only one specification, where the change in neuroticism was regressed on a dummy for unemployed. Otherwise, the coefficients for the unemployment indicators were insignificant. This finding suggests that, although unemployment at young ages might affect personality traits, the impact of unemployment later in life regarding a change in personality traits is likely to be modest.

Besides reverse causality, another potential problem in lagged personality trait measures is the errors-in-variables bias, which occurs if personality traits change during the relevant time period (Almlund et al., 2011). In our case, errors in variables would be induced if a given unemployment spell started after the age of 33 and if the personality traits at the beginning of the 
unemployment were different than those obtained at the age of 33. Although both mean level and rank order stability hold, the errors-in-variables problem cannot be ruled out. Rank order stability can hold even if the scores of the personality traits have changed. In addition, the mean level change could be zero even if there were changes in individuals' trait scores: subsets of individual scores may be increasing and decreasing, thus offsetting each other's changes and resulting in no mean level change (Roberts et al., 2006). ${ }^{12}$ Instead of focusing on changes at the aggregate level, it is also possible to concentrate on changes at the individual level by using the Reliable Change Index (RCI). The RCI assesses whether the change in a personality trait is of sufficient magnitude to be confident that the change is beyond what could be attributed to a measurement error. The RCI is calculated as follows (Jacobson \& Truax, 1991):

$$
R C I=\frac{P_{i, q, 50}-P_{i, q, 33}}{\sqrt{2\left(S_{q}\right)^{2}}}, \text { where } S_{q}=S D_{q, 33} \sqrt{\left(1-r_{q}\right)} \text {. }
$$

In equation (6), $P_{q}$ refers to different personality trait $q, i$ refers to an individual, $S D_{q, 33}$ is the standard deviation of the trait $q$ at age 33, and $r$ is a reliability measure, which is the Cronbach's alpha in our case. If RCI is between -1.96 and 1.96 , there is no significant change in an individual's score in trait $q$. Otherwise, it is unlikely that the difference between test scores at the ages of 33 and 50 is due to a random measurement error, thus the change is reliable $(p<0.05)$. Table 7 tabulates the means and standard deviations of the Big Five personality traits at the ages of 33 and 50 and describes the mean-level change, rank-order stability and individual level change (RCI) between these ages.

\footnotetext{
${ }^{12}$ There can also be a measurement error, which is present at the time of measurement. This measurement error can be attributed to two sources. First, individuals might vary in the extent to which they know themselves and in addition, some individuals might be better self-reporters than others (Pervin, 2003: 429). Second, individuals might give a false personality picture, which is called "socially desirable responding" in psychology. Paulhus (1984) further divided this socially desirable responding into conscious "impression management" and subconscious "self-deception". Although these are both potential sources of measurement error, there is evidence that for instance a husband and wife show a relatively strong agreement on the subject's (husband) score regarding the Big Five Factors - the only exception was neuroticism (Pervin \& John, 2001). Furthermore, Li and Bagger (2006) find in their meta-analysis that impression management and self-deception did not create spurious effects on the relationship between personality measures and performance nor did these concepts function as performance predictors. For further discussion, see e.g. Pervin, 2003: 427-431.
} 
TABLE $7 \quad$ Changes in personality traits between ages 33 and 50 .

\begin{tabular}{|c|c|c|c|c|c|c|c|}
\hline & \multirow[b]{2}{*}{ 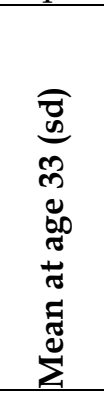 } & \multirow[b]{2}{*}{ 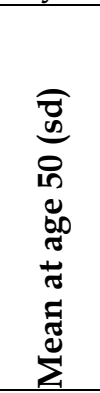 } & \multirow[b]{2}{*}{ 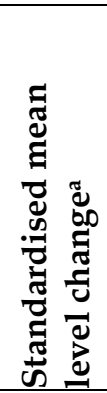 } & \multirow[b]{2}{*}{ 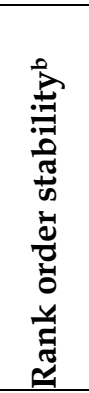 } & \multicolumn{3}{|c|}{$\begin{array}{l}\text { Individual level change } \\
(\mathrm{RCI})^{\mathrm{c}}\end{array}$} \\
\hline & & & & & 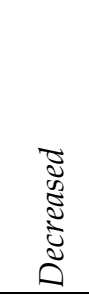 & 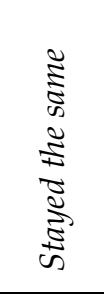 & 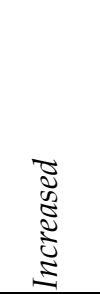 \\
\hline Openness & $\begin{array}{l}3.23 \\
(0.55)\end{array}$ & $\begin{array}{l}3.21 \\
(0.55)\end{array}$ & -0.05 & 0.55 & $42 \%$ & $26 \%$ & $32 \%$ \\
\hline Conscientiousness & $\begin{array}{l}3.60 \\
(0.52)\end{array}$ & $\begin{array}{l}3.68 \\
(0.53)\end{array}$ & 0.14 & 0.50 & $32 \%$ & $21 \%$ & $46 \%$ \\
\hline Extraversion & $\begin{array}{l}3.21 \\
(0.49)\end{array}$ & $\begin{array}{l}3.16 \\
(0.55)\end{array}$ & -0.08 & 0.43 & $46 \%$ & $17 \%$ & $36 \%$ \\
\hline Agreeableness & $\begin{array}{l}3.50 \\
(0.51)\end{array}$ & $\begin{array}{c}3.71 \\
(0.47)\end{array}$ & 0.41 & 0.49 & $18 \%$ & $23 \%$ & $59 \%$ \\
\hline Neuroticism & $\begin{array}{l}2.60 \\
(0.64)\end{array}$ & $\begin{array}{c}2.30 \\
(0.68)\end{array}$ & -0.44 & 0.47 & $66 \%$ & $14 \%$ & $21 \%$ \\
\hline
\end{tabular}

$\mathrm{N}=151$

aStandardised mean level change (i.e., Cohen's d) using standard deviation obtained from pooled measures of personality traits at ages 33 and 50 .

bRank order stability is measured by Kendall's tau-b.

cPercentage of individuals who decreased, stayed the same, or increased on each personality trait, according to the Reliable Change Index.

Table 7 shows that the greatest mean level changes occurred in neuroticism and agreeableness, which decreased and increased, respectively, by about 0.4 standard deviations between the ages of 33 and 50. Rank order stability, measured by Kendall's tau, was the highest for openness and the lowest for extraversion. For our purposes, however, RCI is probably more informative. Table 3 shows which percentage of individuals decreased, increased or stayed the same in each of the personality traits based on the RCI. According to the results, it was rather the rule than an exception that the personality trait scores changed between the ages of 33 and 50. For instance, only 14 percent of individuals had no significant change in their scores of neuroticism, and the score of the most stable personality trait, openness, remained the same only among 26 percent of the sampled individuals. Overall, the results based on the RCI are in line with previous studies, which have found that individuals generally decline in neuroticism, extraversion, and openness and, on the other hand, increase in agreeableness and conscientiousness between adolescence and old age (McCrae, 2009: 151). ${ }^{13}$ It is also worth noting that, although the RCI suggests that there are changes in personality traits, it does not indicate the magnitude of these changes.

${ }^{13}$ In particular, openness increases until sometime in an individual's 20s, after which it slowly declines. (McCrae, 2009: 151) 
In summary, we found some evidence that unemployment at young ages might affect personality traits, but the impact of unemployment later in life on personality traits was likely to be modest. In addition, measurement error is a potential problem because there were significant individual-level changes in personality trait scores over time.

As a robustness check, we used the IV estimation method for Tables 4 and 5 to control for both reverse causality and errors-in-variables. We used the personality traits obtained at age 42 as explanatory variables, and personality traits at age 33 as excluded instruments. Furthermore, a variable describing unemployment between the ages of 15 and 42 was included in the model. In order to ensure that the exclusion restriction was satisfied the unemployment was measured between ages 42 and 50 . Because instrumental variable Tobit and Poisson models did not converge, the results were obtained by 2SLS.

In order to make the estimation period in Table 4 comparable to 2SLS results, we estimated the models of Table 4 by using unemployment between ages 42 and 50 as the dependent variable and personality traits at age 42 as regressors. The tobit results indicated significant positive marginal effects for openness and neuroticim but the marginal effects for extraversion and agreeableness were insignificant. The 2SLS results concerning cumulative duration of unemployment indicated significant positive relationship between openness and unemployment whereas the relationship between extraversion and unemployment was negative and significant. Hence openness was most consistently associated with increased cumulative unemployment and the result held also after controlling for potential reverse causality and errors-invariables. ${ }^{14}$

As for a comparison we also estimated the models of Table 5 by Poisson estimation so that the dependent variable indicated the number of unemployment spells between ages 42 and 50 and personality was measured at age 42. In this case openness was significant in all model specifications and extraversion was significant only in column 4 . The 2SLS results related to the number of unemployment spells indicated a significant positive relationship between neuroticism and the number of unemployment spells in column (1), otherwise the coefficients were insignificant. Therefore the results suggest that the relationship between personality traits and the number of unemployment spells should be interpreted cautiously.

The results in Table 6 suggested that neuroticism was associated with a decreased probability of unemployment exit. However, as the results in this section show, the results concerning neuroticism should be interpreted cautiously because previous unemployment might affect the level of neuroticism at age 33. Therefore the results in Table 6 might be at least partly driven by reverse causality.

14 Child personality characteristics could potentially be used as instruments for adult personality traits. However, we did not have such child personality variables for all five adult personality traits, which would correlate with the adult personality variables, conditional on the other covariates. 


\section{Conclusions}

In this paper, we studied the relationship between personality traits and subsequent unemployment. The results suggested that a higher score in openness was related to a longer cumulative duration of unemployment possibly because openness was related to an increased number of unemployment spells. We also found that extraversion and agreeableness were associated with reduced cumulative unemployment and that extraversion was associated with a reduced number of unemployment spells but these results differed across the model specifications. Finally, the results suggested that neuroticism was associated with a decreased probability of unemployment exit, meaning longer durations of single unemployment spells. However, this result might be at least partly driven by reverse causality.

Of particular note, although openness was related to unemployment in the long run, there was no connection between openness and the duration of a single unemployment spell. Some authors (Uysal \& Pohlmeier, 2011; Kanfer et al., 2001) have found that higher scores in openness decreased the duration of an unemployment spell. Uysal and Pohlmeier propose that open people might be less choosy in their job search and more likely to apply to a variety of jobs. If their reservation wage is also lower than average, openness is likely to decrease the durations of single unemployment spells. However, our results suggest that if this interpretation holds, being less choosy in one's job search might lead to a weaker job match quality, which results in more unemployment spells and thus to extended unemployment in the long run. It is also possible that a higher level of openness might cause individuals to seek out new experiences and new challenges, and this would lead to breaks in an individual's working career over a longer period of time. Individuals with a higher level of openness might also tend to choose occupations in which the risk of unemployment is higher. As far as occupational choices explain the results, differences in unemployment can be a natural outcome of optimal worker/job matching. However, the question of why openness was related to unemployment is beyond the scope of this paper but merits further research.

Another question, which would merit more research in the future is the configuration of the personality characteristics within a person. In this paper, we examined the connections between personality and unemployment by using the Big Five personality traits as such. According to Herzberg and Roth (2006), numerous studies have proposed three major personality prototypes that configure the Big Five personality traits within an individual: 1) Resilients (low score in neuroticism, high or intermediate scores in other traits), 2) Overcontrolled (high neuroticism, low extraversion), and 3) Undercontrolled (low scores in conscientiousness and neuroticism). Using the same JYLS data as in the present study, Kinnunen et al. (in press) also identified the three groups of personality (resilients, overcontrolled, and undercontrolled) with slightly different configurations. They also identified two other groups, namely 
Reserved (high score in conscientiousness, low scores in other traits) and Ordinary individuals (medium score in all traits). Kinnunen et al.'s groups had discriminant power of individuals' subjective health. It is possible that these kinds of combinations of personality traits would provide additional information also about the connections between personality and unemployment, and this could turn out to be a fruitful area of research in the future. 


\section{References}

Almlund, M., Duckworth, A. L., Heckman, J. \& Kautz, T. (2011). Personality psychology in economics. IZA Discussion Paper No. 5500.

Antecol, H. \& Cobb-Clark, D. A. (2010) Do non-cognitive skills help explain the occupational segregation of young people? IZA Discussion Paper No. 5093.

Ardelt, M. (2000). Still stable after all these years? Personality stability theory revisited. Social Psychology Quarterly, 63, 391-405.

Barrick, M. B., \& Mount, M. K. (1991). The Big Five personality dimensions and job performance: a meta-analysis. Personnel Psychology, 44, 1-26.

Bleidorn, W., Kandler, C., Riemann, R., Angleitner, A., \& Spinath, F. M. (2009). Patterns and sources of adult personality development: growth curve analyses of the NEO PI-R scales in a longitudinal twin study, Journal of Personality and Social Psychology. 97, 142-155.

Borghans, L., Duckworth, A. L., Heckman, J. J., \& ter Weel, B. (2008). The economics and psychology of personality traits. Journal of Human Resources. 43, 972-1059.

Braakmann, N. (2009). The role of psychological traits for the gender gap in fulltime employment and wages: Evidence from Germany. SOEP papers on Multidisciplinary Panel Data Research 162.

Burch G., \& Anderson N. (2009). Personality at work. In P. J. Corr, \& G. Matthews (Eds.), The Cambridge Handbook of Personality Psychology (pp.748763). Cambridge, UK: Cambridge University Press.

Caliendo, M., Cobb-Clark, D., \& Uhlendorff, A. (2010). Locus of control and jobsearch strategies, IZA Discussion Paper No. 4750.

Cameron, C., \& Trivedi, P. (2009). Microeconometrics using Stata. College Station, TX: Stata press.

Caspi, A. (1998). Personality development across the life course. In W. Damon (Series Ed.) \& N. Eisenberg (Vol. Ed.), Handbook of child psychology: Vol. 3. Social, emotional, and personality development (5th ed.) (pp. 311-388). New York, NY: Wiley.

Caspi, A., Elder, G. H., Jr., \& Bern, D. J. (1987). Moving against the world: Lifecourse patterns of explosive children. Developmental Psychology, 23, 308313.

Caspi, A., Moffitt, T. E., Thornton, A., Freedman, D., Amell, J. A., Harrington, H., Smeijers, J., \& Silva, P. A. (1996). The life history calendar: a research and clinical assessment method for collecting retrospective event-history data. International Journal of Methods in Psychiatric Research, 6, 101-114.

Caspi, A., Wright, B. R. E., Moffit, T. E., \& Silva, P. A. (1998). Early failure in the labor market: childhood and adolescent predictors of unemployment in the transition to adulthood. American Sociological Review, 63, 424-451.

Cobb-Clark, D. A., \& Schurer, S. (2011). Two economists' musings on the stability of locus of control. IZA Discussion Papers 5630. 
Cobb-Clark, D., \& Tan, M. (2009). Noncognitive skills, occupational attainment, and relative wages. IZA Discussion Paper No. 4289.

Costa, P. T., Jr., \& McCrae, R. R. (1994). "Set like a plaster"?: Evidence for stability of adult personality. In T. Heatherton, \& J. Weinberger (Eds.), Can personality Change? (pp- 21-40). Washington, DC: American Psychological Association.

Costa, P. T., Jr., \& McCrae, R. R. (1985). The NEO personality inventory manual, Odessa, FL: Psychological Assessment Resources.

DellaVigna, S., \& Paserman, M. D. (2005). Job search and impatience. Journal of Labor Economics, 23(31), 527-588.

Dooley, D., \& Prause, J. (1995). Effects of unemployment on school-leavers' selfesteem. Journal of Occupational and Organizational Psychology, 68, 177-192.

Dooley, D., \& Prause, J. (1997). Effect of students' self-esteem on later employment status: Interactions of self-esteem with gender and race. Applied Psychology: An International Review, 46, 175-198.

Eisenberg, P., \& Lazarsfeld, P. F. (1938). The psychological effects of unemployment. Psychological Bulletin 35 (6), 358-390.

Farkas, G. (2003). Cognitive skills and noncognitive traits and behaviors in stratification process. Annual Review of Sociology, 29, 541-562.

Feinstein, L. (2000). The relative economic importance of academic, psychologycal, and behavioural attributes developed in childhood. CEP Discussion Paper dp0443.

Ferguson, D. M., Horwood, L. J., \& Lynskey, M. T. (1997). The effects of unemployment on psychiatric illness during young adulthood. Psychological Medicine, 27, 371-381.

Filer, R. K. (1986). The role of personality and tastes in determining occupational structure. Industrial and Labor Relations Review 39 (3), 412-424.

Gallo, W. T., Endrass, J., Bradley, E. H., Hell, D., \& Kasl, S. V. (2003). The influence of internal control on the employment status of german workers. Schmollers Jahrbuch, 123(1), 71-81.

Heckman, J. J., Stixrud, J., \& Urzua, S. (2006). The effects of cognitive and noncognitive abilities on labour market outcomes and social behavior. Journal of Labor Economics, 24(31), 411-482.

Heineck, G. (2011). Does it pay to be nice? Personality and earnings in the United Kingdom. Industrial and Labor Relations Review, 64 (5), 1020-1038.

Herzberg, P. Y., \& Roth, M. (2006). Beyond resilients, undercontrollers, and overcontrollers? An extension of personality prototype research. European Journal of Personality, 20, 5-28.

Hintsanen, M., Lipsanen, J., Pulkki-Råback, L., Kivimäki, M., Hintsa, T., \& Keltikangas-Järvinen, L. (2009). EAS temperaments as predictors of unemployment in young adults: A 9-year follow-up of the Cardiovaskular Risk in Young Finns Study. Journal of Research in Personality, 43(4), 618-623.

Jacobson, N. S., \& Truax, P. (1991). Clinical significance: a statistical approach to defining meaningful change in psychotherapy research. Journal of Consulting and Clinical Psychology, 59, 12-19. 
Kanfer, R., Wanberg, C. R., \& Kantrowitz, T. M. (2001). Job search and employment: a personality-motivational analysis and meta-analytic review. Journal of Applied Psychology, 86(5), 837-855.

Kinnunen, M.-L., Metsäpelto, R.-L., Feldt, T., Kokko, K., Tolvanen, A., Kinnunen, U., Leppänen, E., \& Pulkkinen, L. (in press). Personality profiles and their associations with health. Scandinavian Journal of Psychology.

Kokko, K., Bergman, L. R. \& Pulkkinen, L. (2003). Child personality characteristics and selection into long-term unemployment in Finnish and Swedish longitudinal samples. International Journal of Behavioral Development, 27(2), 134-144.

Kokko, K., \& Pulkkinen, L. (2000). Aggression in childhood and long-term unemployment in adulthood: a cycle of maladaptation and some protective factors. Developmental Psychology, 36, 463-472.

Li, A., \& Bagger, J. (2006). Using the BIDR to distinguish the effects of impresssion management and self-deception on the criterion validity of personality measures: a meta-analysis. International Journal of Selection $\mathcal{E}$ Assessment, 14, 131-141.

McCrae, R. R. (2009). The five-factor model of personality traits: consensus and controversy. In P. J. Corr, \& G. Matthews (Eds.) The Cambridge Handbook of Personality Psychology (pp. 148-161). Cambridge, New York: Cambridge University Press.

McCrae, R. R., \& Costa, P. T., Jr. (2008). The five-factor theory of personality. In O. P. John, R. W. Robins \& L. A. Pervin (Eds.), Handbook of personality: Theory and research (3rd ed.) (pp. 159-181). New York: The Guilford Press.

McCrae, R. R., \& Costa, T. T., Jr. (2006). Personality in adulthood: a five-factor theory perspective. New York, NY: A Division of Guilford Publications, Inc.

McGee, A. (2010). How the perception of control influences unemployed job search. In Essays on the role of noncognitive skills on decisionmaking. Dissertation, 1-50. The Ohio State University.

Mohanty, M. S. (2010). Effects of positive attitude and optimism on employment: evidence from the US data. Journal of Socio-Economics, 39, 258-270.

Mueller, G., \& Plug, E. (2006). Estimating the effect of personality on male and female earnings. Industrial and Labour Relations Review, 60(1), 3-22.

Murphy, G. C., \& Athanasou, J. A. (1999). The effects of unemployment on mental health. Journal of Occupational and Organizational Psychology, 72, 8399.

Musek, J. (2007). A general factor of personality: Evidence for the Big One in the five-factor model. Journal of Research in Personality, 41, 1213-1233.

Nyhus, E. K., \& Pons, E. (2005). The effects of personality on earnings. Journal of Economic Psychology, 26, 363-384.

Paulhus, D. L. (1984). Two-component models of socially desirable responding. Journal of Personality and Social Psychology, 46, 598-609. 
Pervin, L. A. (2003). The science of personality. (2nd ed.) New York: Oxford University Press.

Pervin, L. A., \& John, O. P. (2001). Personality: Theory and Research. New York: Wiley.

Pitkänen, L. (1969). A descriptive model of aggression and nonaggression with applications to children's behaviour. Jyväskylä Studies in Education, Psychology and Social Research, Nr. 19, University of Jyväskylä, Finland.

Pulkkinen, L. (2009) Development and aging personality: a resource or risk for successful development. Scandinavian Journal of Psychology, 50, 602-620.

Pulkkinen, L. (2006) The Jyväskylä longitudinal study of personality and social development. In L. Pulkkinen, J. Kaprio, \& R. J. Rose (Eds.), Socioemotional development and health from adolescence to adulthood (pp. 29-55). New York: Cambridge University Press.

Pulkkinen, L. \& Kokko, K. (2012) Foundational issues in longitudinal data collection. In B. Laursen, T. D. Little \& N. A. Card (Eds.), Handbook of developmental research methods (pp. 129-147). New York, NY, US: The Guilford Press.

Pulkkinen, L., \& Kokko, K. (2010). Keski-ikä elämänvaiheena. Reports from the Department of Psychology University of Jyväskylä, 352. (in Finnish)

Pulkkinen, L., Kokko, K., \& Rantanen, J. (2012). Paths from socio-emotional behavior in middle childhood to personality in middle adulthood. Developmental Psychology. Advance online publication.

Pulver, A., Allik, J., Pulkkinen, L., \& Hämäläinen, M. (1995). A Big Five personality inventory in two non-Indo-European languages. European Journal of Personality, 9, 109-124.

Rantanen, J., Metsäpelto, R.-L., Feldt, T., Pulkkinen, L., \& Kokko, K. (2007). Long-term stability in the Big Five personality traits in adulthood. Scandinavian Journal of Psychology, 48(6), 511-518.

Roberts, B. W., \& DelVecchio, W. F. (2000). The rank-order consistency of personality traits from childhood to old age: a qualitative review of longitudinal studies. Psychological Bulletin, 126, 3-25.

Roberts, B. W., Walton, K. E., \& Viechtbauer, W. (2006). Patterns of mean-level change in personality traits across the life course: a meta-analysis of longitudinal studies. Psychological Bulletin, 132(1), 1-25.

Scollon, C. N., \& Diener, E. (2006). Love, work, and changes in extraversion and neuroticism over time. Journal of Personality and Social Psychology, 91, 11521165.

Specht, J., Egloff, B., \& Schmukle, S. (2011). Stability and change of personality across the life course: the impact of age and major life events on mean-level and rank-order stability of the Big Five. SOEPpapers on Multidisciplinary Panel Data Research, 377. (forthcoming in Journal of Personality and Social Psychology).

Srivastava, S., John, O. P., Gosling, S. D., \& Potter, J. (2003). Development of personality in early and middle adulthood: set like a plaster or persistent change? Journal of Personality and Social Psychology, 84(5), 1041-1053. 
Sutin, A. R., \& Costa, P. T., Jr. (2010). Reciprocal influences of personality and job characteristics across middle adulthood. Journal of Personality, 78, 257288.

Sutin A. R., Costa Jr P. T., Miech R., \& Eaton W. W. (2009). Personality and career success: concurrent and longitudinal relations. European Journal of Personality, 23, 71-84.

Tobin, J. (1958). Estimation of relationship for limited dependent variables. Econometrica, 26, 24-36.

Tokar D. M., Fischer A. R., \& Subich L. M. (1998). Personality and vocational behavior: a selective review of the literature, 1993-1997. Journal of Vocational Behavior, 53, 115-153.

Uysal, S. D., \& Pohlmeier, W. (2011). Unemployment duration and personality. Journal of Economic Psychology, 32(6), 980-992.

Wichert, L., \& Pohlmeier, W. (2010). Female labour force participation and the Big Five. Centre for European Economic Research (ZEW), Mannheim, Discussion Paper No. 10-003.

Winefield, A. H., Winefield, H. R., Tiggemann, M., \& Goldney, R. D. (1991). A longitudinal study of the psychological effects of unemployment and unsatisfactory employment on young adults. Journal of Applied Psychology, 76(3), 424-431. 


\section{Appendix A}

Total results of Table 4. Cumulative duration of unemployment between the ages of 33 and 50 (Tobit).

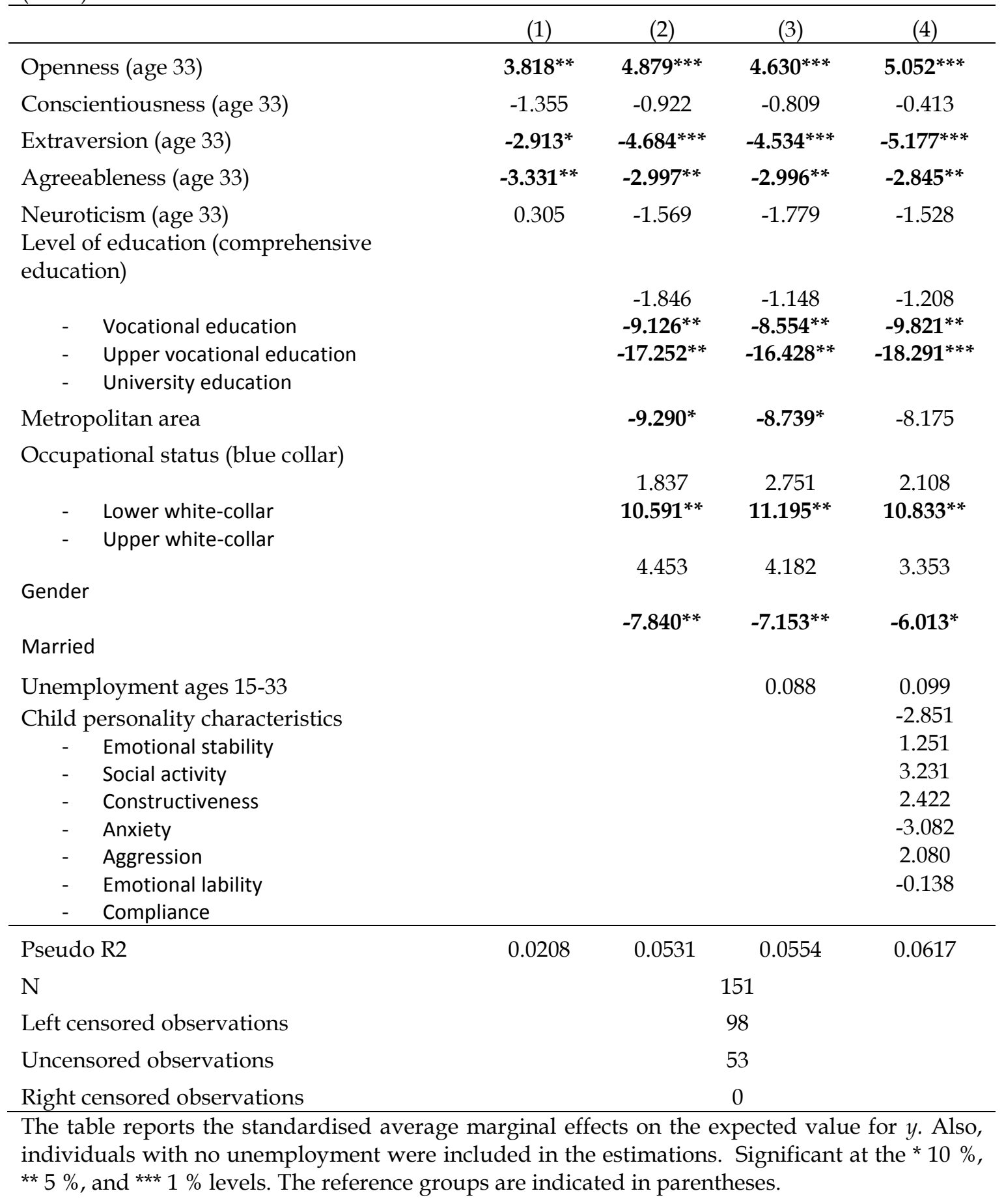




\section{Appendix B}

Total results of Table 5. Personality and the number of unemployment spells (Poisson model).

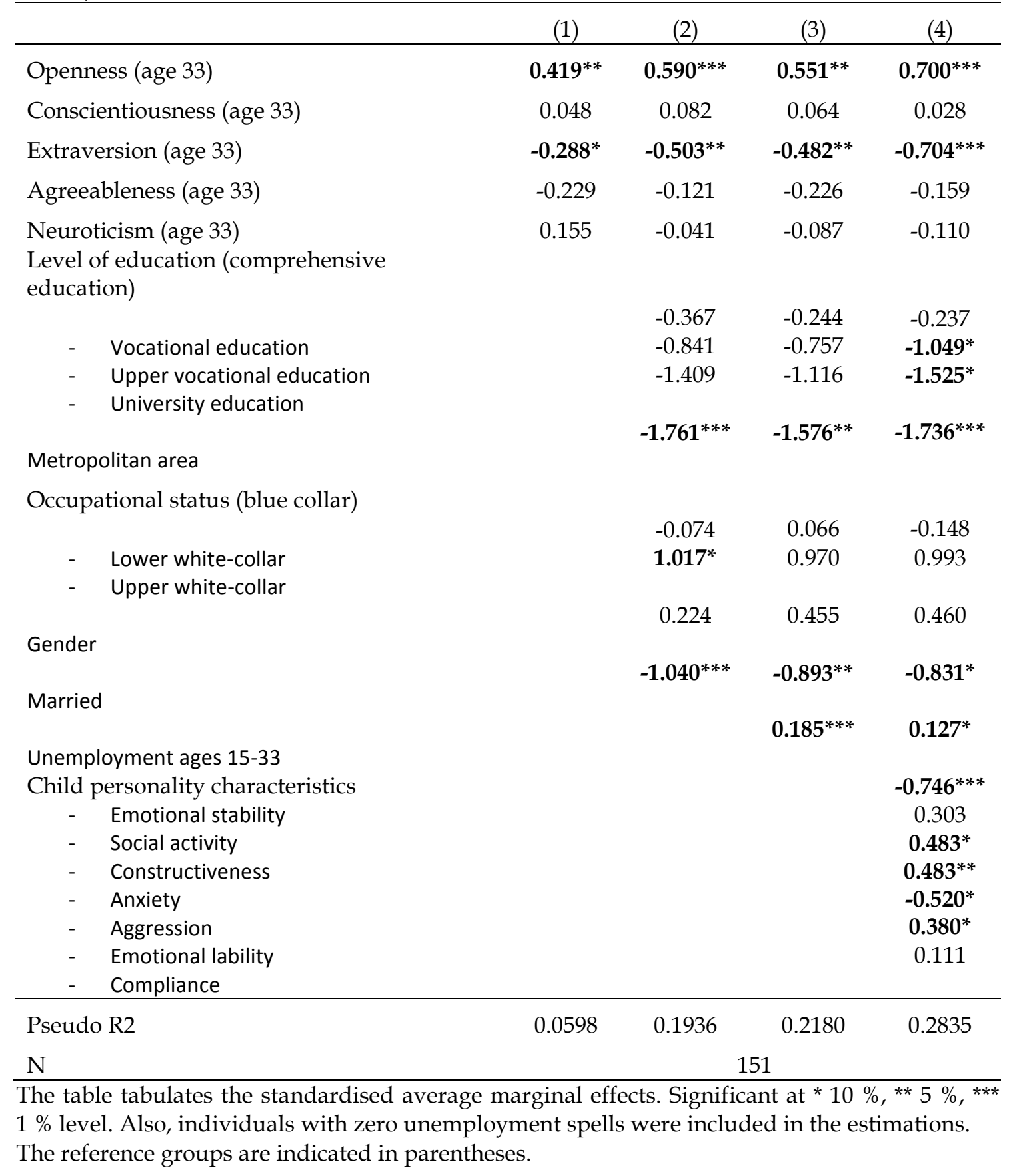




\section{Appendix C}

Total results of Table 6. Durations of single unemployment spells (discrete time proportional hazard regression model).

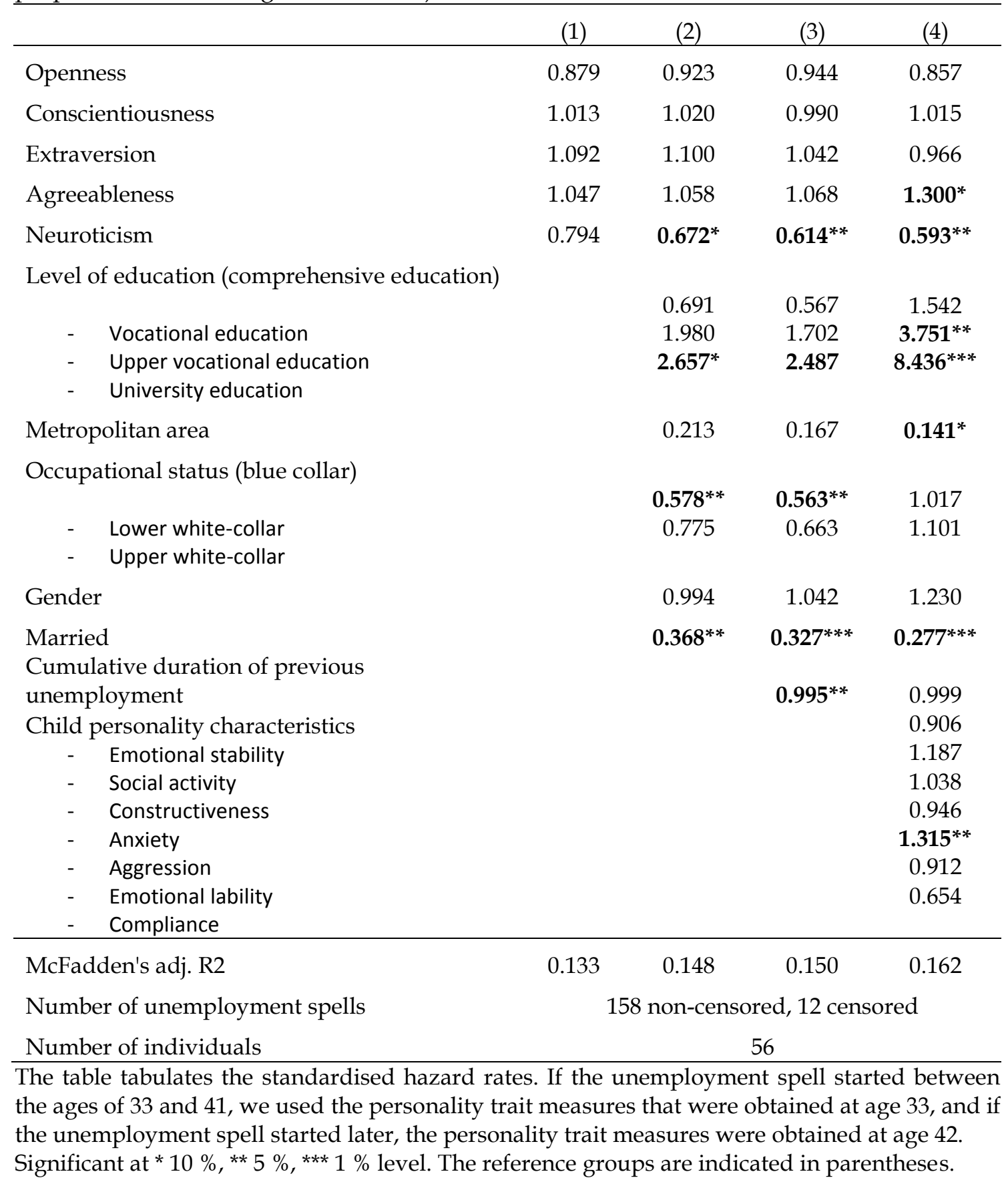




\section{Appendix D}

TABLE D.1 Relationship between unemployment and change in personality traits between ages 15 and 33 (OLS).

\begin{tabular}{|c|c|c|c|c|}
\hline $\begin{array}{l}\text { Dependent } \\
\text { variable }\end{array}$ & Explanatory variables & (1) & (2) & (3) \\
\hline \multirow[t]{4}{*}{ Openness } & Unemployment indicator & $\begin{array}{c}\mathbf{- 0 . 1 8 8 * *} \\
(0.089)\end{array}$ & $\begin{array}{l}-0.094 \\
(0.089)\end{array}$ & $\begin{array}{l}-0.092 \\
(0.093)\end{array}$ \\
\hline & Additional controls ${ }^{a}$ & & $x$ & $x$ \\
\hline & Controls: child personality characteristics ${ }^{b}$ & & & $x$ \\
\hline & Adj. R2 & 0.0224 & 0.1068 & 0.0781 \\
\hline \multirow[t]{4}{*}{$\begin{array}{l}\text { Conscientious } \\
\text { ness }\end{array}$} & Unemployment indicator & $\begin{array}{l}-0.247^{* * *} \\
(0.083)\end{array}$ & $\begin{array}{l}-0.224^{* *} \\
(0.088)\end{array}$ & $\begin{array}{c}-0.243^{* * *} \\
(0.090)\end{array}$ \\
\hline & Additional controlsa & & $x$ & $x$ \\
\hline & Controls: child personality characteristics ${ }^{b}$ & & & $x$ \\
\hline & Adj. R2 & 0.0493 & 0.0277 & 0.0264 \\
\hline \multirow[t]{4}{*}{ Extraversion } & Unemployment indicator & $\begin{array}{c}-\mathbf{0 . 1 7 4} 4^{* *} \\
(0.079)\end{array}$ & $\begin{array}{c}-0.158^{* *} \\
(0.079)\end{array}$ & $\begin{array}{c}-\mathbf{0 . 1 7 1 * *} \\
(0.079)\end{array}$ \\
\hline & Additional controlsa & & $x$ & $x$ \\
\hline & Controls: child personality characteristics ${ }^{b}$ & & & $x$ \\
\hline & Adj. R2 & 0.0247 & 0.1159 & 0.1537 \\
\hline \multirow[t]{4}{*}{ Agreeableness } & Unemployment indicator & $\begin{array}{l}-0.038 \\
(0.084)\end{array}$ & $\begin{array}{c}0.048 \\
(0.086)\end{array}$ & $\begin{array}{c}0.040 \\
(0.086)\end{array}$ \\
\hline & Additional controlsa & & $x$ & $x$ \\
\hline & Controls: child personality characteristics ${ }^{b}$ & & & $x$ \\
\hline & Adj. R2 & -0.005 & 0.0570 & 0.0964 \\
\hline \multirow[t]{4}{*}{ Neuroticism } & Unemployment indicator & $\begin{array}{l}0.120 \\
(0.105)\end{array}$ & $\begin{array}{c}0.119 \\
(0.100)\end{array}$ & $\begin{array}{c}0.123 \\
(0.104)\end{array}$ \\
\hline & Additional controls ${ }^{\mathrm{a}}$ & & $x$ & $x$ \\
\hline & Controls: child personality characteristics ${ }^{b}$ & & & $x$ \\
\hline & Adj. R2 & 0.0020 & 0.1670 & 0.1347 \\
\hline \multicolumn{5}{|c|}{$\begin{array}{l}\mathrm{N}=151 \text {. Standard errors are reported in parentheses. Significant at } * 10 \%, * * \%, * * * 1 \% \text { levels. } \\
\text { Unemployment indicator equals one for those individuals who have experienced at least one } \\
\text { unemployment spell between ages } 33 \text { and } 50 \text {. } \\
\text { a Additional controls: education, occupation, gender and marital status. The indicator for } \\
\text { metropolitan area was excluded from the set of explanatory variables because unemployment } \\
\text { might have affected this variable (i.e., individuals who become unemployed move to the } \\
\text { metropolitan area to improve their reemployment possibilities). } \\
\text { b The child personality characteristics were as follows: emotional stability, social activity, } \\
\text { constructiveness, anxiety, aggression, emotional lability, and compliance, and they were } \\
\text { obtained at age } 8 \text {. }\end{array}$} \\
\hline
\end{tabular}


TABLE D.2 The effect of previous cumulative unemployment on the Big Five personality traits at age 33 (OLS).

\begin{tabular}{|c|c|c|c|c|}
\hline $\begin{array}{l}\text { Dependent } \\
\text { variable }\end{array}$ & Explanatory variables & (1) & (2) & (3) \\
\hline \multirow[t]{5}{*}{ Openness } & Cumulative unemployment ages $15-33$ & 0.0001 & 0.003 & 0.003 \\
\hline & & $(0.003)$ & $(0.003)$ & $(0.003)$ \\
\hline & Additional controls ${ }^{a}$ & & $\mathrm{x}$ & $\mathrm{x}$ \\
\hline & Controls: child personality characteristics ${ }^{b}$ & & & $x$ \\
\hline & Adj. R2 & -0.0067 & 0.1090 & 0.0822 \\
\hline \multirow{5}{*}{$\begin{array}{l}\text { Conscientious } \\
\text { ness }\end{array}$} & Cumulative unemployment ages $15-33$ & $-0.004^{*}$ & -0.003 & $-0.005^{*}$ \\
\hline & & $(0.002)$ & $(0.003)$ & $(0.003)$ \\
\hline & Additional controls ${ }^{\mathrm{a}}$ & & $x$ & $x$ \\
\hline & Controls: child personality characteristics ${ }^{b}$ & & & $x$ \\
\hline & Adj. R2 & 0.0134 & -0.0065 & -0.0051 \\
\hline \multirow[t]{5}{*}{ Extraversion } & Cumulative unemployment ages $15-33$ & -0.003 & -0.002 & -0.001 \\
\hline & & $(0.002)$ & $(0.002)$ & $(0.002)$ \\
\hline & Additional controls ${ }^{\mathrm{a}}$ & & $x$ & $x$ \\
\hline & Controls: child personality characteristics ${ }^{\mathrm{b}}$ & & & $x$ \\
\hline & Adj. R2 & 0.0024 & 0.0945 & 0.1260 \\
\hline \multirow[t]{5}{*}{ Agreeableness } & Cumulative unemployment ages $15-33$ & -0.002 & 0.0005 & -.0001 \\
\hline & & $(0.002)$ & $(0.003)$ & $(0.003)$ \\
\hline & Additional controls ${ }^{\mathrm{a}}$ & & $x$ & $x$ \\
\hline & Controls: child personality characteristics ${ }^{b}$ & & & $x$ \\
\hline & Adj. R2 & -0.0036 & 0.0551 & 0.0950 \\
\hline \multirow[t]{4}{*}{ Neuroticism } & Cumulative unemployment ages $15-33$ & $\begin{array}{c}\mathbf{0 . 0 0 9}^{* * *} \\
(0.003)\end{array}$ & $\begin{array}{c}0.005 \\
(0.003)\end{array}$ & $\begin{array}{c}0.004 \\
(0.003)\end{array}$ \\
\hline & Additional controlsa & & $x$ & $x$ \\
\hline & Controls: child personality characteristics ${ }^{b}$ & & & $x$ \\
\hline & Adj. R2 & 0.0512 & 0.1741 & 0.1382 \\
\hline \multicolumn{5}{|c|}{$\begin{array}{l}\mathrm{N}=151 \text {. Standard errors are reported in parentheses. Significant at }{ }^{*} 10 \%, * * 5 \%,{ }^{* *} 1 \% \text { levels. } \\
\text { Unemployment was measured as cumulative unemployment between ages } 15 \text { and } 33 \text {. } \\
\text { a Additional controls: education, occupation, gender and marital status. } \\
\text { b The child personality characteristics were as follows: emotional stability, social activity, } \\
\text { constructiveness, anxiety, aggression, emotional lability, and compliance, and they were } \\
\text { obtained at age } 8 \text {. }\end{array}$} \\
\hline
\end{tabular}


TABLE D.3 The effect of the number of previous unemployment spells on the Big Five personality traits at age 33 (OLS).

\begin{tabular}{|c|c|c|c|c|}
\hline $\begin{array}{l}\text { Dependent } \\
\text { variable }\end{array}$ & Explanatory variables & $(1)$ & $(2)$ & (3) \\
\hline \multirow[t]{5}{*}{ Openness } & $\begin{array}{l}\text { Number of unemployment spells ages 15- } \\
33\end{array}$ & -0.041 & -0.001 & 0.006 \\
\hline & & $(0.032)$ & $(0.032)$ & $(0.034)$ \\
\hline & Additional controlsa & & $\mathrm{x}$ & $\mathrm{x}$ \\
\hline & Controls: child personality characteristics ${ }^{b}$ & & & $\mathrm{x}$ \\
\hline & Adj. R2 & 0.0044 & 0.0998 & 0.0716 \\
\hline \multirow[t]{5}{*}{$\begin{array}{l}\text { Conscientiousne } \\
\text { ss }\end{array}$} & $\begin{array}{l}\text { Number of unemployment spells ages 15- } \\
33\end{array}$ & $-0.051^{*}$ & -0.038 & -0.045 \\
\hline & & $(0.030)$ & $(0.032)$ & $(0.033)$ \\
\hline & Additional controls ${ }^{a}$ & & $x$ & $x$ \\
\hline & Controls: child personality characteristics $b$ & & & $\mathrm{x}$ \\
\hline & Adj. R2 & 0.0125 & -0.0058 & -0.0117 \\
\hline \multirow[t]{5}{*}{ Extraversion } & $\begin{array}{l}\text { Number of unemployment spells ages } 15- \\
33\end{array}$ & -0.035 & -0.021 & -0.022 \\
\hline & & $(0.028)$ & $(0.028)$ & $(0.029)$ \\
\hline & Additional controls ${ }^{a}$ & & $\mathrm{x}$ & $\mathrm{x}$ \\
\hline & Controls: child personality characteristics ${ }^{b}$ & & & $x$ \\
\hline & Adj. R2 & 0.0033 & 0.0943 & 0.1281 \\
\hline \multirow[t]{5}{*}{ Agreeableness } & $\begin{array}{l}\text { Number of unemployment spells ages 15- } \\
33\end{array}$ & 0.008 & 0.044 & $0.064^{* *}$ \\
\hline & & $(0.039)$ & $(0.030)$ & $(0.030)$ \\
\hline & Additional controls ${ }^{a}$ & & $\mathrm{x}$ & $\mathrm{x}$ \\
\hline & Controls: child personality characteristics ${ }^{b}$ & & & $x$ \\
\hline & Adj. R2 & -0.0062 & 0.0688 & 0.1235 \\
\hline \multirow[t]{5}{*}{ Neuroticism } & $\begin{array}{l}\text { Number of unemployment spells ages 15- } \\
33\end{array}$ & 0.051 & 0.038 & 0.043 \\
\hline & & $(0.037)$ & $(0.036)$ & $(0.038)$ \\
\hline & Additional controls ${ }^{a}$ & & $\mathrm{x}$ & $\mathrm{x}$ \\
\hline & Controls: child personality characteristics ${ }^{b}$ & & & $x$ \\
\hline & Adj. R2 & 0.0062 & 0.1653 & 0.1342 \\
\hline \multicolumn{5}{|c|}{$\begin{array}{l}\mathrm{N}=151 \text {. Standard errors are reported in parentheses. Significant at } * 10 \%, * * 5 \%,{ }^{* * *} 1 \% \text { levels. } \\
\text { Unemployment was measured as cumulative duration of unemployment between ages } 15 \text { and } \\
33 \text {. } \\
\text { a Additional controls: education, occupation, gender and marital status. } \\
\text { b The child personality characteristics were as follows: emotional stability, social activity, } \\
\text { constructiveness, anxiety, aggression, emotional lability and compliance, and they were } \\
\text { obtained at age } 8 \text {. }\end{array}$} \\
\hline
\end{tabular}


TABLE D.4 Relationship between unemployment and change in personality traits between ages 33 and 50 (OLS).

\begin{tabular}{|c|c|c|c|c|}
\hline $\begin{array}{l}\text { Dependent } \\
\text { variable }\end{array}$ & Explanatory variables & $(1)$ & $(2)$ & (3) \\
\hline \multirow[t]{5}{*}{ Openness } & Unemployment indicator & -0.110 & -0.101 & -0.107 \\
\hline & & $(0.068)$ & $(0.072)$ & $(0.072)$ \\
\hline & Additional controls ${ }^{\mathrm{a}}$ & & $x$ & $x$ \\
\hline & Controls: child personality characteristics ${ }^{b}$ & & & $x$ \\
\hline & Adj. R2 & 0.0106 & -0.0009 & 0.0130 \\
\hline \multirow[t]{4}{*}{$\begin{array}{l}\text { Conscientious } \\
\text { ness }\end{array}$} & Unemployment indicator & $\begin{array}{l}-0.077 \\
(0.074)\end{array}$ & $\begin{array}{l}-0.088 \\
(0.077)\end{array}$ & $\begin{array}{l}-0.093 \\
(0.079)\end{array}$ \\
\hline & Additional controls ${ }^{\mathrm{a}}$ & & $x$ & $x$ \\
\hline & Controls: child personality characteristics ${ }^{b}$ & & & $x$ \\
\hline & Adj. R2 & 0.0005 & 0.0027 & -0.0294 \\
\hline \multirow[t]{5}{*}{ Extraversion } & Unemployment indicator & -0.087 & -0.085 & -0.088 \\
\hline & & $(0.082)$ & $(0.086)$ & $(0.085)$ \\
\hline & Additional controls ${ }^{\mathrm{a}}$ & & $x$ & $x$ \\
\hline & Controls: child personality characteristics ${ }^{b}$ & & & $x$ \\
\hline & Adj. R2 & 0.0009 & 0.0043 & 0.0257 \\
\hline \multirow[t]{4}{*}{ Agreeableness } & Unemployment indicator & $\begin{array}{l}-0.017 \\
(0.067)\end{array}$ & $\begin{array}{l}-0.031 \\
(0.069)\end{array}$ & $\begin{array}{l}-0.030 \\
(0.071)\end{array}$ \\
\hline & Additional controlsa & & $x$ & $x$ \\
\hline & Controls: child personality characteristics ${ }^{b}$ & & & $x$ \\
\hline & Adj. R2 & -0.0063 & 0.0125 & -0.0139 \\
\hline \multirow[t]{4}{*}{ Neuroticism } & Unemployment indicator & $\begin{array}{c}0.118 \\
(0.096)\end{array}$ & $\begin{array}{l}\text { 0.179* } \\
(0.098)\end{array}$ & $\begin{array}{c}0.155 \\
(0.100)\end{array}$ \\
\hline & Additional controlsa & & $x$ & $x$ \\
\hline & Controls: child personality characteristics b & & & $\mathrm{x}$ \\
\hline & Adj. R2 & 0.0035 & 0.0319 & 0.0242 \\
\hline \multicolumn{5}{|c|}{$\begin{array}{l}\mathrm{N}=151 \text {. Standard errors are reported in parentheses. Significant at } * 10 \%, * * 5 \%,{ }^{* * *} 1 \% \text { levels. } \\
\text { Unemployment indicator equals one for those individuals who have experienced at least one } \\
\text { unemployment spell between ages } 33 \text { and } 50 \text {. } \\
\text { a Additional controls: education, occupation, gender and marital status. } \\
\text { b The child personality characteristics were as follows: emotional stability, social activity, } \\
\text { constructiveness, anxiety, aggression, emotional lability, and compliance, and they were } \\
\text { obtained at age } 8 \text {. }\end{array}$} \\
\hline
\end{tabular}


TABLE D.5 Relationship between cumulative unemployment and change in personality traits between ages 33 and 50 (OLS).

\begin{tabular}{|c|c|c|c|c|}
\hline $\begin{array}{l}\text { Dependent } \\
\text { variable }\end{array}$ & Explanatory variables & (1) & (2) & (3) \\
\hline \multirow[t]{4}{*}{ Openness } & Cumulative unemployment ages $33-50$ & $\begin{array}{l}-0.002 \\
(0.002)\end{array}$ & $\begin{array}{l}-0.002 \\
(0.002)\end{array}$ & $\begin{array}{l}-0.002 \\
(0.002)\end{array}$ \\
\hline & Additional controls ${ }^{\mathrm{a}}$ & & $x$ & $x$ \\
\hline & Controls: child personality characteristics ${ }^{\mathrm{b}}$ & & & $x$ \\
\hline & Adj. R2 & 0.0077 & 0.0023 & 0.0132 \\
\hline \multirow[t]{3}{*}{$\begin{array}{l}\text { Conscientious } \\
\text { ness }\end{array}$} & Cumulative unemployment ages $33-50$ & $\begin{array}{l}-0.003 \\
(0.002)\end{array}$ & $\begin{array}{l}-0.003 \\
(0.002)\end{array}$ & $\begin{array}{l}-0.003 \\
(0.002)\end{array}$ \\
\hline & Additional controlsa & & $x$ & $x$ \\
\hline & Controls: child personality characteristics ${ }^{b}$ & & & $x$ \\
\hline \multirow[t]{4}{*}{ Extraversion } & $\begin{array}{l}\text { Adj. R2 } \\
\text { Cumulative unemployment ages 33-50 }\end{array}$ & $\begin{array}{l}0.0106 \\
-0.001 \\
(0.002)\end{array}$ & $\begin{array}{l}0.0112 \\
-0.001 \\
(0.002)\end{array}$ & $\begin{array}{c}-0.0238 \\
0.000 \\
(0.002)\end{array}$ \\
\hline & Additional controls ${ }^{\mathrm{a}}$ & & $x$ & $x$ \\
\hline & Controls: child personality characteristics ${ }^{b}$ & & & $x$ \\
\hline & Adj. R2 & -0.0055 & -0.0021 & 0.0180 \\
\hline \multirow[t]{3}{*}{ Agreeableness } & Cumulative unemployment ages $33-50$ & $\begin{array}{l}0.0005 \\
(0.001)\end{array}$ & $\begin{array}{r}-0.0002 \\
(0.002)\end{array}$ & $\begin{array}{c}-0.0004 \\
(0.002)\end{array}$ \\
\hline & Additional controls ${ }^{a}$ & & $x$ & $x$ \\
\hline & Controls: child personality characteristics ${ }^{b}$ & & & $x$ \\
\hline \multirow[t]{4}{*}{ Neuroticism } & $\begin{array}{l}\text { Adj. R2 } \\
\text { Cumulative unemployment ages } 33-50\end{array}$ & $\begin{array}{c}-0.0060 \\
-0.001 \\
(0.002)\end{array}$ & $\begin{array}{c}0.0113 \\
0.001 \\
(0.002)\end{array}$ & $\begin{array}{c}-0.0148 \\
0.001 \\
(0.002)\end{array}$ \\
\hline & Additional controls ${ }^{a}$ & & $x$ & $x$ \\
\hline & Controls: child personality characteristics ${ }^{b}$ & & & $x$ \\
\hline & Adj. R2 & -0.0050 & 0.0099 & 0.0078 \\
\hline \multicolumn{5}{|c|}{$\begin{array}{l}\mathrm{N}=151 \text {. Standard errors are reported in parentheses. Significant at * } 10 \%, * * 5 \%, * * * 1 \% \text { levels. } \\
\text { Unemployment was measured as cumulative unemployment between ages } 33 \text { and } 50 \text {. } \\
\text { a Additional controls: education, occupation, gender and marital status. } \\
\text { b The child personality characteristics were as follows: emotional stability, social activity, } \\
\text { constructiveness, anxiety, aggression, emotional lability, and compliance, and they were } \\
\text { obtained at age } 8 \text {. }\end{array}$} \\
\hline
\end{tabular}


TABLE D.6 Relationship between number of unemployment spells and change in personality traits between ages 33 and 50 (OLS).

\begin{tabular}{|c|c|c|c|c|}
\hline $\begin{array}{l}\text { Dependent } \\
\text { variable }\end{array}$ & Explanatory variables & $(1)$ & (2) & (3) \\
\hline \multirow[t]{4}{*}{ Openness } & Number of unemployment spells & $\begin{array}{l}-0.020 \\
(0.015)\end{array}$ & $\begin{array}{l}-0.021 \\
(0.015)\end{array}$ & $\begin{array}{l}-0.019 \\
(0.016)\end{array}$ \\
\hline & Additional controls ${ }^{a}$ & & $x$ & $x$ \\
\hline & Controls: child personality characteristics ${ }^{\mathrm{b}}$ & & & $x$ \\
\hline & Adj. R2 & 0.0056 & -0.0023 & 0.0071 \\
\hline \multirow[t]{4}{*}{$\begin{array}{l}\text { Conscientious } \\
\text { ness }\end{array}$} & Number of unemployment spells & $\begin{array}{l}-0.003 \\
(0.016)\end{array}$ & $\begin{array}{c}0.001 \\
(0.017)\end{array}$ & $\begin{array}{c}0.003 \\
(0.018)\end{array}$ \\
\hline & Additional controls ${ }^{a}$ & & $x$ & $x$ \\
\hline & Controls: child personality characteristics ${ }^{b}$ & & & $x$ \\
\hline & Adj. R2 & -0.0065 & -0.0064 & -0.0399 \\
\hline \multirow[t]{4}{*}{ Extraversion } & Number of unemployment spells & $\begin{array}{l}-0.011 \\
(0.018)\end{array}$ & $\begin{array}{l}-0.011 \\
(0.019)\end{array}$ & $\begin{array}{l}-0.001 \\
(0.019)\end{array}$ \\
\hline & Additional controls ${ }^{a}$ & & $x$ & $x$ \\
\hline & Controls: child personality characteristics ${ }^{b}$ & & & $x$ \\
\hline & Adj. R2 & -0.0043 & -0.0003 & 0.0180 \\
\hline \multirow[t]{4}{*}{ Agreeableness } & Number of unemployment spells & $\begin{array}{l}-0.007 \\
(0.014)\end{array}$ & $\begin{array}{l}-0.013 \\
(0.015)\end{array}$ & $\begin{array}{l}-0.016 \\
(0.016)\end{array}$ \\
\hline & Additional controls ${ }^{a}$ & & $x$ & $x$ \\
\hline & Controls: child personality characteristics ${ }^{b}$ & & & $x$ \\
\hline & Adj. R2 & -0.0050 & 0.0163 & -0.0078 \\
\hline \multirow[t]{4}{*}{ Neuroticism } & Number of unemployment spells & $\begin{array}{l}-0.010 \\
(0.021)\end{array}$ & $\begin{array}{c}0.006 \\
(0.021)\end{array}$ & $\begin{array}{c}0.006 \\
(0.022)\end{array}$ \\
\hline & Additional controlsa & & $x$ & $x$ \\
\hline & Controls: child personality characteristics ${ }^{b}$ & & & $x$ \\
\hline & Adj. R2 & -0.0052 & 0.0099 & 0.0073 \\
\hline \multicolumn{5}{|c|}{$\begin{array}{l}\mathrm{N}=151 \text {. Standard errors are reported in parentheses. Significant at * } 10 \%, * * 5 \%, * * * 1 \% \text { levels. } \\
\text { Unemployment was measured as number of unemployment spells between ages } 33 \text { and } 50 \text {. } \\
\text { a Additional controls: education, occupation, gender and marital status. } \\
\text { b The child personality characteristics were as follows: emotional stability, social activity } \\
\text { constructiveness, anxiety, aggression, emotional lability, and compliance, and they were } \\
\text { obtained at age } 8 \text {. }\end{array}$} \\
\hline
\end{tabular}

